\title{
Continuous in vitro culture of the carpet shell clam Tapes decussatus protozoan parasite Perkinsus atlanticus
}

\author{
Sandra M. Casas ${ }^{1}$, Jerome F. La Peyre ${ }^{2}$, Kimberly S. Reece ${ }^{3}$, Carlos Azevedo ${ }^{4}$, \\ Antonio Villalba ${ }^{1, *}$ \\ ${ }^{1}$ Centro de Investigacións Mariñas, Consellería de Pesca e Asuntos Marítimos, Xunta de Galicia, Aptdo. 13, \\ 36620 Vilanova de Arousa, Spain \\ ${ }^{2}$ Cooperative Aquatic Animal Health Research Program, Department of Veterinary Science, \\ Louisiana State University Agricultural Center, Baton Rouge, Louisiana 70803, USA \\ ${ }^{3}$ School of Marine Science, Virginia Institute of Marine Science, The College of William and Mary, Gloucester Point, \\ Virginia 23062, USA \\ ${ }^{4}$ Department of Cellular Biology, Institute of Biomedical Sciences, University of Oporto, 4050 Porto, Portugal
}

\begin{abstract}
Continuous in vitro cultures of the clam Tapes decussatus parasite Perkinsus atlanticus were established from infected gill fragments, infected haemolymph and parasite hypnospores isolated from infected gill fragments following incubation in Ray's fluid thioglycollate medium (RFTM). No continuous cultures could be initiated from P. atlanticus zoospores. Cultures initiated from hypnospores yielded the highest percentage of continuous cultures $(100 \%, 6 / 6)$, followed by cultures initiated from gill fragments $(93 \%, 43 / 46)$ and from haemolymph $(30 \%, 3 / 10)$. Failures to establish continuous cultures were due to microbial contamination. The source of parasite influenced the success rate, the time taken to establish cultures and the size of cultured cells. In vitro proliferation of parasite cells was mainly by vegetative multiplication. Zoosporulation, yielding motile biflagellated zoospores, was observed at a low frequency $(<1 \%$ of dividing cells) in every culture. Morphology of cultured cells examined with light and transmission electron microscopy corresponded to that of $P$. atlanticus found in clam tissues. Cultured cells enlarged in RFTM and stained blue-black with Lugol's solution, which are characteristics of the Perkinsus species cells. DNA sequences of the internal transcribed spacer (ITS) region of the ribosomal RNA gene complex matched those of $P$. atlanticus. All cultures were established in a medium designated JL-ODRP-2A that was similar in composition to the culture medium JL-ODRP-1 originally used to propagate Perkinsus marinus in vitro. Proliferation of $P$. atlanticus in vitro could be supported by the commercial culture medium (1:2 v/v) DME:Ham's F-12 with fetuin.
\end{abstract}

KEY WORDS: Perkinsus atlanticus - Tapes decussatus $\cdot$ In vitro culture $\cdot$ Clam parasite $\cdot$ Ribosomal RNA gene complex $\cdot$ ITS $\cdot$ Ultrastructure

Resale or republication not permitted without written consent of the publisher

\section{INTRODUCTION}

Perkinsus atlanticus has been associated with mass mortalities of the carpet shell clam Tapes decussatus in estuarine regions of the Portuguese and Spanish coasts

${ }^{*}$ Corresponding author. Email: villalba@cimacoron.org
(Ruano \& Cachola 1986, Azevedo 1989, Santmartí et al. 1995). This protozoan parasite was designated as a new Perkinsus species by Azevedo (1989) based on gross morphological and ultrastructural features of various stages of its life cycle. Further evidence that $P$. atlanticus belongs to the genus Perkinsus was provided from nucleotide sequence analysis of the small subunit (SSU) rRNA gene and the internal transcribed 
spacer (ITS) region of the rRNA gene complex (Goggin 1994, de la Herrán et al. 2000, Robledo et al. 2000, Casas et al. 2002). Recently, Ordás \& Figueras (1998) reported the in vitro culture of $P$. atlanticus from the haemolymph of an infected carpet shell clam. Identification of the cultured cells was based solely on their morphology (light and electron microscopy). Sequence analysis of the SSU small subunit rRNA gene, however, showed that those cultured cells did not correspond to a Perkinsus organism (Figueras et al. 2000). Continuous cultures of $P$. atlanticus, therefore, still need to be established.

The development of continuous cultures of Perkinsus species can lead to a better understanding of this group of parasites (La Peyre 1996). Cultures of the eastern oyster pathogen Perkinsus marinus, for example, have been used in a wide range of studies to address the parasite's environmental tolerance (Burreson et al. 1994, Dungan \& Hamilton 1995), virulence (La Peyre et al. 1995, Bushek \& Allen 1996a, Volety \& Chu 1997), genetic composition (Reece et al. 1997, Reece et al. 2001), metabolism (Soudant et al. 2000, Soudant \& Chu 2001) and drug sensitivity (Krantz 1994, Faisal et al. 1999). Since the original culture of $P$. marinus, there have been reports of at least 2 additional Perkinsus species, $P$. chesapeaki and $P$. andrewsi, being propagated in vitro. McLaughlin \& Faisal (1998) cultured 2 protozoa from the gill (G117) and haemolymph (H49) of an infected softshell clam (Mya arenaria). The gill isolate G117 was further characterised as a new Perkinsus species, P. chesapeaki (Kotob et al. 1999, McLaughlin et al. 2000). Perkinsus parasites of infected Baltic clams Macoma balthica were cultured by Kleinschuster et al. (1994) and Coss et al. (2001a). The parasite cultured by Coss et al. (2001b) was designated as a new Perkinsus species, $P$. andrewsi.

Continuous cultures of Perkinsus chesapeaki and of $P$. andrewsi were established using procedures developed to propagate $P$. marinus. These procedures varied greatly among researchers in the type of medium used, the culture conditions and the method used for the establishment of $P$. marinus primary cultures (reviewed in La Peyre 1996). P. marinus and $P$. chesapeaki were propagated in the culture medium JL-ODRP-1 originally formulated to resemble the composition of eastern oyster plasma (La Peyre et al. 1993, McLaughlin \& Faisal 1998). Commercial media including DMEM:Ham's F-12 and Leibowitz's L-15 medium, with various nutritional supplements, were used to culture P. marinus and P. andrewsi (Gauthier \& Vasta 1993, Kleinschuster \& Swink 1993, Kleinschuster et al. 1994, Dungan \& Hamilton 1995, Coss et al. 2001a). Cultures of the 3 Perkinsus spp. have been established from various sources including hearts, visceral ganglia and haemolymph of eastern oysters, gills and haemolymph of a softshell clam, and heart and haemolymph of baltic clams (Gauthier \& Vasta 1993, Kleinschuster \& Swink 1993, La Peyre et al. 1993, McLaughlin \& Faisal 1998, Coss et al. 2001a). Parasite hypnospores isolated from infected eastern oyster tissues incubated in Ray's fluid thioglycollate medium (RFTM) were used to quickly establish $P$. marinus continuous cultures from different geographical regions (La Peyre \& Faisal 1995, Bushek \& Allen 1996b). It is not known which source of parasites, if any, is optimal to establish continuous cultures of Perkinsus spp.

This article describes procedures for the continuous in vitro culture of Perkinsus atlanticus and provides evidence that the cultured cells are $P$. atlanticus. Four different sources of parasite from infected carpet shell clams were tested to establish $P$. atlanticus cultures. They included gills, haemolymph, hypnospores isolated from infected gill fragments after incubation in RFTM, and zoospores isolated after zoosporulation of hypnospores in seawater. To confirm that the cultured cells were $P$. atlanticus, they were characterised by ascertaining (1) their morphology at the light and electron microscopic levels, (2) their ability to enlarge in RFTM and subsequently to stain with Lugol's iodine solution as described by Ray (1966), and (3) the nucleotide sequence of the ITS region of the rRNA gene complex. Finally, the growth rates of 9 isolates, 3 established from the gills, 3 established from haemolymph, and 3 established from hypnospores, were compared in the culture medium JL-ODRP-2A. Concurrently, proliferation of the $3 P$. atlanticus gill isolates was also evaluated in the commercial medium DMEM:Ham's F-12 supplemented with fetuin.

\section{MATERIALS AND METHODS}

Clams. Carpet shell clams Tapes decussatus (40 to $45 \mathrm{~mm}$ ) were collected from an intertidal natural bed in the Ría de Arousa (Galicia, NW Spain) at Vilalonga in May 2000. Fifty clams were maintained for $12 \mathrm{~d}$ in a $75 \mathrm{l}$ tank containing $0.22 \mu \mathrm{m}$ filtered estuarine seawater at $25 \mathrm{ppt}$ and $15^{\circ} \mathrm{C}$. Water in the tank was aerated and recirculated through an ultraviolet steriliser to reduce the clams' bacterial content. Twenty clams with the highest numbers of whitish pustules on their gill surfaces (a conspicuous sign of infection by Perkinsus atlanticus) were selected for P. atlanticus isolation and culture.

Culture medium. The growth culture medium JLODRP-2A was used to establish and maintain Perkinsus atlanticus cultures. This medium was similar in composition to the culture medium JL-ODRP-1 originally used to propagate $P$. marinus in vitro (La Peyre et 
al. 1993) except for a few modifications. JL-ODRP-2A did not contain bovine serum albumin. Chloramphenicol in JL-ODRP-1 was replaced by $0.1 \mathrm{~g} \mathrm{l}^{-1}$ kanamycin, $0.025 \mathrm{~g} \mathrm{l}^{-1}$ gentamycin and $100000 \mathrm{U} \mathrm{l}^{-1}$ penicillin $\mathrm{G}$ in JL-ODRP-2A. The Seawater Synthetic Basal Salt Mixture of JL-ODRP-1, which was no longer available from Sigma Chemical Co., was substituted by a buffered balanced salt solution prepared by dissolving $\left(\mathrm{l}^{-1}\right) 1.323 \mathrm{~g} \mathrm{CaCl} 2 \cdot 2 \mathrm{H}_{2} \mathrm{O}, 2.406 \mathrm{~g} \mathrm{MgSO}_{4}, 3.726 \mathrm{~g}$ $\mathrm{MgCl}_{2} \cdot 7 \mathrm{H}_{2} \mathrm{O}, 1.117 \mathrm{~g} \mathrm{KCl}, 19.293 \mathrm{~g} \mathrm{NaCl}$, and $0.336 \mathrm{~g}$ $\mathrm{NaHCO}_{3}$ in tissue culture grade water. All chemicals used in the medium were of tissue culture grade and from Sigma Chemical Co. unless otherwise indicated. The osmolality of JL-ODRP-2A was 780 mOsm $\mathrm{kg}^{-1}$ with $\mathrm{pH}$ 7.4.

Initiation of cultures from the haemolymph. Haemolymph (ca. $750 \mu l$ ) was withdrawn with a sterile $2 \mathrm{ml}$ syringe and 23 gauge $(\mathrm{G})$ needle from the posterior adductor muscles of the selected clams. To avoid haemocyte clumping and reduce bacterial contamination, the syringe was filled with $750 \mu \mathrm{l}$ of chilled anticlumping saline solution with antibiotics $(803 \mathrm{mOsm}$ $\mathrm{kg}^{-1}$ ) consisting of $\left(\mathrm{l}^{-1}\right) 1.773 \mathrm{~g} \mathrm{NaSO}_{4}, 0.930 \mathrm{~g} \mathrm{KCl}_{1} 21$ g NaCl, $0.350 \mathrm{~g} \mathrm{NaHCO}_{3}, 5 \mathrm{~g}$ EDTA, $0.05 \mathrm{~g}$ kanamycin A, $0.025 \mathrm{~g}$ gentamycin, and $100000 \mathrm{U}$ penicillin $\mathrm{G}$ in sterile tissue culture grade water. Haemolymph was centrifuged $\left(800 \times g, 10 \mathrm{~min}, 4^{\circ} \mathrm{C}\right)$ and the cell pellet was washed $\left(800 \times g, 10 \mathrm{~min}, 4^{\circ} \mathrm{C}\right) 3$ times with a chilled saline solution with antibiotics (803 $\mathrm{mOsm} \mathrm{kg}^{-1}$ ) consisting of $\left(\mathrm{l}^{-1}\right) 1.773 \mathrm{~g} \mathrm{NaSO}_{4}, 0.930 \mathrm{~g} \mathrm{KCl}^{2} 21.5 \mathrm{~g}$ $\mathrm{NaCl}, 0.350 \mathrm{~g} \mathrm{NaHCO}_{3}, 0.05 \mathrm{~g}$ kanamycin A, $0.025 \mathrm{~g}$ gentamycin and $100000 \mathrm{U}$ penicillin $\mathrm{G}$ dissolved in tissue culture grade water. Haemolymph cells, consisting of clam haemocytes and parasites, were seeded in 24well plates with $1 \mathrm{ml}$ of JL-ODRP-2A culture medium in each well and incubated in a humidified chamber at $26^{\circ} \mathrm{C}$. A total of 10 cultures was initiated from haemolymph. The progress of the cultures was checked with an inverted light microscope on Days 3, 4, 12, and 22 after seeding.

Initiation of cultures from the gills. After withdrawing haemolymph, $5 \mathrm{~mm}^{2}$ fragments of gills with whitish pustules were excised with sterile scissors in a laminar flow hood and added to $50 \mathrm{ml}$ test tubes with $30 \mathrm{ml}$ of 25 ppt artificial seawater (ASW, Hawaii Marine Imports). The gill fragments were rinsed 10 times in $30 \mathrm{ml}$ of ASW. They were decontaminated with two 30 min incubations in an antibiotic solution (AS) consisting of $\left(\mathrm{l}^{-1}\right) 400000 \mathrm{U}$ penicillin $\mathrm{G}, 0.4 \mathrm{~g}$ streptomycin sulphate, $0.2 \mathrm{~g}$ gentamycin, $0.4 \mathrm{~g}$ kanamycin $\mathrm{A}, 0.2 \mathrm{mg}$ neomycin, $0.2 \mathrm{~g}$ polymyxin $\mathrm{B}$, and $0.4 \mathrm{~g}$ erithromycin in sterile ASW. Gill fragments were rinsed again 10 times in $30 \mathrm{ml} \mathrm{ASW}$. At least 4 gill fragments were randomly chosen from each clam. Two fragments were placed directly in a $25 \mathrm{~cm}^{2}$ culture flask and 2 fragments were first finely minced with a sterile razor blade before placement in a $25 \mathrm{~cm}^{2}$ culture flask. All of these gill fragments were incubated in $5 \mathrm{ml}$ of JL-ODRP-2A medium per flask, at $26^{\circ} \mathrm{C}$. A total of 46 cultures was initiated from gill fragments of 10 clams. The progress of the cultures was checked with an inverted light microscope on Days 4, 12, and 22 after seeding.

Initiation of cultures from hypnospores. Some gill fragments, decontaminated as described previously, were incubated in Ray's fluid thioglycollate medium without agar (ARFTM, Sigma \#A-0465), for $1 \mathrm{wk}$ in the dark at room temperature $\left(22\right.$ to $\left.26^{\circ} \mathrm{C}\right)$, to induce hypnospore formation (Ray 1966, Nickens et al. 2000). The gill fragments were dissociated with $0.1 \mathrm{~g} \mathrm{l}^{-1}$ pronase in ASW for $1 \mathrm{~h}$. Hypnospores freed from gill fragments were rinsed 3 times in $30 \mathrm{ml}$ ASW with $0.1 \mathrm{~g}$ $\mathrm{l}^{-1}$ mucin $(600 \times \mathrm{g}, 10 \mathrm{~min})$, decontaminated with two 30 min incubations in the antibiotic solution AS (600 $\times$ $g, 10 \mathrm{~min}$ ), and were rinsed again 3 times in $30 \mathrm{ml} \mathrm{ASW}$ with $0.1 \mathrm{~g} \mathrm{l}^{-1}$ mucin $(600 \times g, 10 \mathrm{~min})$. Hypnospores were separated from tissue debris by centrifuging in ASW $(50 \times g, 3 \mathrm{~min})$. The resulting supernatant containing the hypnospores was centrifuged twice in ASW $(400 \times g, 10 \mathrm{~min})$ to pellet the hypnospores. Hypnospores were seeded in 24 -well plates $\left(10^{4}\right.$ cells per well) in $1 \mathrm{ml}$ of JL-ODRP-2A culture medium in each well, and incubated at $26^{\circ} \mathrm{C}$ in a humidified chamber. A total of 6 cultures was initiated from hypnospores. The progress of the cultures was checked with an inverted light microscope on Days 3 and 13 after seeding.

Initiation of cultures from zoospores. Decontaminated gill fragments were incubated in RFTM (Ray 1966) for $1 \mathrm{wk}$ in the dark at room temperature, to induce hypnospore formation. The hypnospores were isolated following the procedure of J. I. Navas (authors' pers. comm.), who modified previously reported methods (Perkins \& Menzel 1966, Chu \& Greene 1989). Briefly, the gill fragments were dissociated with $2.5 \mathrm{~g}$ $\mathrm{l}^{-1}$ trypsin for $90 \mathrm{~min}$. The hypnospores were separated from tissue debris by progressive filtration through a series of sieves of 300, 160, 100 and $20 \mu \mathrm{m}$. Hypnospores retained in the $20 \mu \mathrm{m}$ sieve were rinsed 10 times in $30 \mathrm{ml} \mathrm{ASW}(600 \times g, 10 \mathrm{~min})$. They were decontaminated with two $30 \mathrm{~min}$ incubations in the antibiotic solution AS and rinsed 10 times in $30 \mathrm{ml}$ ASW. Hypnospores were incubated in sterile, filtered $(0.22 \mu \mathrm{m})$ seawater for $4 \mathrm{~d}$ at $28^{\circ} \mathrm{C}$ to induce zoosporulation. Free zoospores were separated from hypnospores using a $10 \mu \mathrm{m}$ sieve that retained the latter. Zoospores were then pelleted $(3000 \times g, 20 \mathrm{~min})$. Zoospores were seeded in each well of a 24 -well plate $\left(10^{5}\right.$ zoospores per well), with $1 \mathrm{ml}$ of JL-ODRP-2A culture medium per well, and incubated at $26^{\circ} \mathrm{C}$, in a humidified chamber. The progress of the cultures was checked 
with an inverted light microscope on Days 7, 14, 21, and 45 after seeding.

Maintenance of cultures. Subculturing was performed 1 mo after the cultures were started, when parasite proliferation had given rise to a high number of cells. Clam cells did not multiply in the culture medium and eventually died. Cells in culture flasks and wells were harvested and passed 3 times through a $23 \mathrm{G}$ needle with a $10 \mathrm{ml}$ syringe to break up cell aggregates. The cells were rinsed 3 times in culture medium $\left(800 \times g, 15 \mathrm{~min}, 25^{\circ} \mathrm{C}\right)$. Cell viability was assessed by staining with $50 \mathrm{mg} \mathrm{l}^{-1}$ neutral red, and $5 \times$ $10^{6}$ cells were transferred into a new flask in $5 \mathrm{ml}$ of JLODRP-2A culture medium. Subculturing was repeated every 4 to $6 \mathrm{wk}$.

Characterisation of the cultured cells: microscopy. The morphology of the cultured cells following subculturing was observed with a light microscope using differential interference contrast optics. The ultrastructure of 3 Perkinsus atlanticus isolates established from gill fragments was examined on Days 2, 14 and 90 after subculturing. The ultrastructure of $1 P$. atlanticus isolate established from haemolymph was also examined on Day 5 after subculturing. Cells were harvested and pelleted by centrifugation at $800 \times g$ for $15 \mathrm{~min}$. Cell pellets were fixed for $2 \mathrm{~h}$ with $2.5 \%$ glutaraldehyde in $0.2 \mathrm{M}$ sodium cacodylate buffer, $\mathrm{pH} 7.2$ at $4^{\circ} \mathrm{C}$. The pellets were washed twice in cacodylate buffer and post-fixed for $2 \mathrm{~h}$ in $2 \% \mathrm{OsO}_{4}$ in cacodylate buffer at $4{ }^{\circ} \mathrm{C}$. The cells were enrobed with $1.5 \%$ agar solution. The agar blocks were dehydrated in an ethanol series and embedded in Epon. Ultra-thin sections were double-stained with uranyl acetate and lead citrate and examined with a JEOL 100 CXII transmission electron microscope (TEM) operated at $60 \mathrm{kV}$.

Characterisation: DNA sequencing. Genomic DNA was isolated from cultured cells as previously described by Reece et al. (1997) for Perkinsus marinus cultures. Isolations were done from 5 different isolate cultures established from gills of 5 infected clams as well as from 2 haemolymph and 2 hypnospore cultures. PCR primers used were designed in a previous study to specifically target the ITS region of the ribosomal RNA gene unit of all Perkinsus species except $P$. qugwadi (Casas et al. 2002). The primer pair designated 'D' was used to amplify an approximately $675 \mathrm{bp}$ fragment of the ITS region from genomic DNA of the cultured P. atlanticus. PCR amplification, cloning and sequencing was done as previously described (Casas et al. 2002).

The resulting ITS region sequences were subjected to BLAST searches (Altschul et al. 1990) of the National Center for Biotechnology Information (NCBI) GenBank database and were aligned to available ITS sequences for Perkinsus spp. (Goggin 1994-GenBank accession numbers PAU07697, PMU07700, POU07701, PSU07698, PSU07699, Robledo et al. 2000 — accession number AF140295, Coss et al. 2001b-accession numbers AF252288, AF102171, S.I. Kotob et al. unpubl._accession numbers AF091541, AF091542, AF126022, AF150988, AF150989, AF150990, G.D. Brown et al. unpubl. — accession numbers AF149876, AF150985, AF150986, AF150987, C.A. Coss et al. unpubl. - accession number AF252288, Casas et al. 2002-accession numbers AF369967, AF369968, AF369969, AF369970, AF369971, AF369972, AF369973, AF369974, AF369975, AF369976, AF369977, AF369978, AF369979). Sequences were aligned using the CLUSTAL-W algorithm (Thompson et al. 1994) in the MacVector 7.0 DNA Sequence Analysis Software package (Oxford Molecular). Parsimony bootstrap analysis of Perkinsus ITS sequences was performed using PAUP* 4b8.0 (Swofford 2001) with 100 bootstrap resamplings of 100 random addition replicates. Nineteen of the ITS region sequences from the $P$. atlanticus cultures were deposited in GenBank under the following accession numbers: AF441207-AF441218 and AF472517-AF472523.

Characterisation: enlargement of cultured cells in RFTM. The enlargement of cultured cells in RFTM was tested for 9 different isolates, 3 established from gill fragments, 3 established from haemolymph and 3 established from hypnospores. Cells of each isolate were washed and suspended in ASW, and seeded in 24-well plates with $2 \mathrm{ml}$ of RFTM in each well at a density of $0.5 \times 10^{5}$ cells per ml. The plates were incubated for $1 \mathrm{wk}$ at room temperature in the dark. The diameter of 50 random cells from each well was measured before and after incubation in RFTM. Cells incubated in RFTM for $1 \mathrm{wk}$ were stained with diluted Lugol's solution (Ray 1966). Cell viability was determined with $50 \mathrm{mg} \mathrm{l}^{-1}$ neutral red before and after incubation in RFTM.

Growth measurements of Perkinsus atlanticus in JL-ODRP-2A and DMEM/F-12. The growth rates of 9 different $P$. atlanticus isolates, 3 established from gills, 3 established from haemolymph and 3 established from hypnospores, were compared in the culture medium JL-ODRP-2A. The isolates were subcultured twice before measuring their growth rates. New subcultures were performed from each flask by transferring $12 \times 10^{6}$ cells into a flask with $12 \mathrm{ml}$ of JL-ODRP2A culture medium. Additionally, 3 culture flasks containing $3 P$. atlanticus isolates established from gills were set up in 1:2 DME/Ham's F-12 culture medium (790 mOsm kg-1, pH 6.6) supplemented with $1.7 \mathrm{mg} \mathrm{l}^{-1}$ fetuin, $100 \mathrm{U} \mathrm{ml}^{-1}$ of penicillin $\mathrm{G}$ and streptomycin sulphate, and buffered with $50 \mathrm{mM}$ Hepes and $3.7 \mathrm{mM}$ sodium bicarbonate (Gauthier et al. 1995). Samples of $0.5 \mathrm{ml}$ were collected on Days $2,4,6,9,12,15,18,22$, 
25, and 30 after seeding and were passed 3 times through a $23 \mathrm{G}$ needle with a $10 \mathrm{ml}$ syringe to break up cell aggregates. Cell density was measured with a Malassez haemocytometer. Cell viability was assessed by staining with $50 \mathrm{mg} \mathrm{l}^{-1}$ neutral red. Growth rate was calculated as doubling time (DT), the time for a population to double in number during the period of maximum proliferation. The diameter of at least 50 cells per isolate was measured on Days 2 and 4 . The diameter of cells in vegetative division per isolate was measured and the number of daughter cells per mother cell was counted on Day 15.

Statistical analysis. Differences in doubling time, cell diameter and number of daughter cells per mother cell between culture origins were tested by means of 1way analysis of variance, using MINITAB software. Paired comparisons were performed using the Fisher's (PLSD) test. Cell diameter and number of daughter cells per mother cell were $\log _{10}$-transformed before statistical analysis to assure homogeneity of variance. Differences in cell diameter before and after incubation in RFTM were tested in the same way.

\section{RESULTS}

\section{Establishment of cultures in vitro}

Thirty percent (3/10) of cultures initiated from haemolymph yielded continuous cultures. Sixty percent $(6 / 10)$ of haemolymph cultures were contaminated by bacteria and thraustochytrid-like organisms by Day 3. No parasite cells were observed in the remaining $10 \%(1 / 10)$ of the cultures after $22 \mathrm{~d}$. Haemocytes were dominant and few parasite cells were seen in the wells on Day 4 . On Day 12, about $35 \%$ of the parasite cells were involved in vegetative multiplication. The percentage of hypnospores in the wells was lower than $1 \%$ and zoosporulation was rarely observed. On Day 22 more than $90 \%$ of parasite cells were in vegetative multiplication.

The percentage of cultures initiated from gill fragments yielding continuous cultures was 93\% (43/46). Bacteria and/or thraustochytrid-like organisms contaminated the remaining cultures. Gill fragments in culture medium gradually lost their architecture and Perkinsus atlanticus cells progressively became free of the tissues. Very few cells of $P$. atlanticus, free of gill tissue, were seen in the flasks on Days 4 and 8 after seeding. On Day 12, the number of free parasite cells was still low although some stages of vegetative multiplication were observed in most flasks. The percentage of hypnospores in the flasks was lower than $1 \%$ and zoosporulation was rarely seen. On Day 22, more than $90 \%$ of parasite cells were in vegetative multiplication.
In addition, some immature trophozoites arising from multiplication were observed. No difference was detected between using infected gill fragments or finely minced infected gill as inoculum.

Every culture (6/6) initiated from hypnospores yielded a continuous culture. On Day 3, $96.2 \pm 0.92 \%$ of hypnospores were not dividing, $2.8 \pm 1.36 \%$ were in zoosporulation and $1 \pm 0.45 \%$ were in vegetative multiplication $(\mathrm{N}=3$ cultures, mean $\pm \mathrm{SD}$ ). On Day 13, more than $90 \%$ of parasite cells were in vegetative multiplication.

No continuous cultures were successfully established from zoospores. There were no signs of division or zoospore transformation in any of the zoospore cultures even though none of these cultures was contaminated. The number of live zoospores decreased progressively until no viable zoospores were observed on Day 45 after seeding.

\section{Morphology of cultured cells}

Cultured cells observed by light microscopy were mostly spherical, with the cytoplasm enclosing 1 or more refractile bodies (presumably lipid droplets) and a prominent vacuole (Fig. 1), which occasionally contained a vacuoplast. Nuclei were peripheral. Cell diameter varied from 2 to $37 \mu \mathrm{m}$. Cells usually occurred in clumps. Cell enlargement was followed by division after the first signs of cell cleavage were observed (Fig. 2). Subsequently, daughter cells became distinguishable forming tight clusters (Fig. 3). The daughter cells enlarged inside the mother cell (Figs. $4 \& 5$ ) and were freed following rupture of the mother cell wall (Fig. 6). The number of daughter cells produced by each mother cell varied from 2 to ca. 60 . Counting daughter cells was difficult due to their tight clumping. The initial diameter of daughter cells varied from 2 to $5 \mu \mathrm{m}$. Daughter cells still in contact could divide further, thus producing large clusters of daughter cells. Cells maintained in culture without a change of medium for an extended period of time ( 5 mo) developed a large vacuole and could lose their lipid droplets (Fig. 7). Hypnospores with a thick wall, discharge tube, and a variable number of prezoospores/zoospores inside (Fig. 8) were observed in all the cultures at a low frequency. Motile biflagellated zoospores were eventually liberated from these hypnospores.

Ultrastructurally, the cytoplasm of cultured cells $2 \mathrm{~d}$ after subculture showed numerous vesicles, lipid droplets, endoplasmic reticulum, small mitochondria with tubular cristae and vacuoles. Some of the vacuoles contained vacuoplasts. Each cell nucleus showed a prominent nucleolus (Fig. 9). Lomosomes were also 

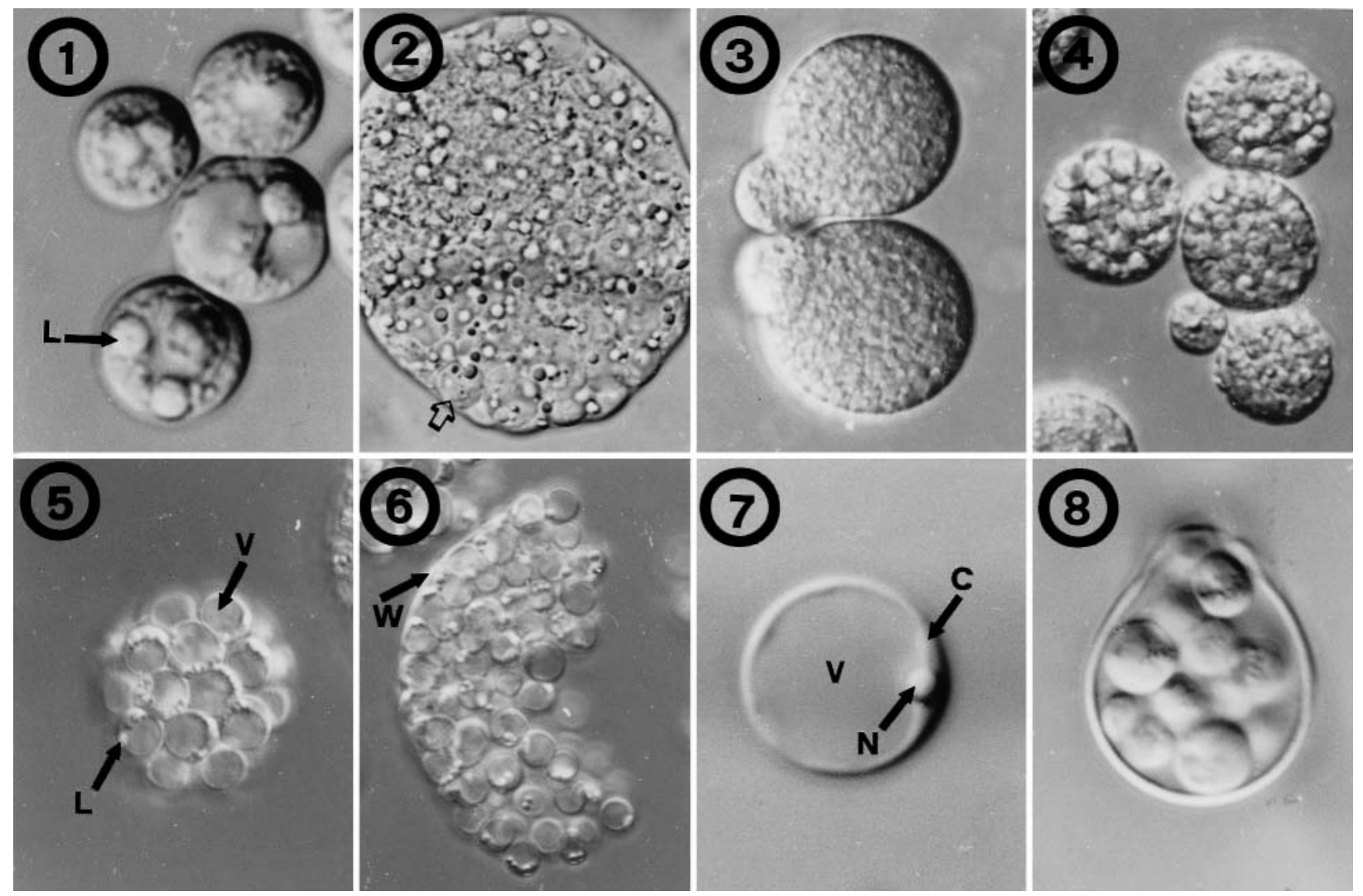

Figs. 1-8. Perkinsus atlanticus. Light micrographs of cultured cells in JL-ODRP-2A medium. Fig. 1. Cultured cells in fresh medium with dense cytoplasm containing refractile lipid droplets (1800×). Fig. 2. Enlarged cell in vegetative multiplication showing signs of cell cleavage and individualisation of some peripheral daughter cells (arrow) (1100x). Fig. 3. Two cells in vegetative multiplication with well-developed cleavage furrows and tightly packed daughter cells (800×). Fig. 4. Larger and loosely packed daughter cells inside mother cells (800x). Fig. 5. Enlarged daughter cells inside mother cells containing welldefined vacuoles and several lipid droplets $(1100 \times)$. Fig. 6. Daughter cells released from a mother cell after rupture of its cell wall $(1100 \times)$. Fig. 7. Cultured cell maintained 3 mo without a medium change with cytoplasm containing no lipid droplets and occupied by an enlarged vacuole without vacuoplast (2300×). Fig. 8. Zoospores in zoosporangium (800×). C: cytoplasm. L: lipid droplet. N: nucleus. V: vacuole. W: wall

observed between the cell wall and plasmalemma of some cells. Cells sampled $5 \mathrm{~d}$ after subculture had enlarged and their cell walls had become thicker (Fig. 10). Vegetative division involved fragmentation of the vacuoles (Figs. $11 \& 12$ ); then multinucleated stages with incomplete cleavage of the cytoplasm were observed (Fig. 11). Subsequently, every nucleus was surrounded by a portion of cytoplasm, which was membrane-limited. Daughter cells were very tightly packed within the mother cell wall, which remained intact (Fig. 12). On Day 14, the cytoplasm of cultured cells had a large vacuole lacking vacuoplast, lipid droplets and mitochondria, and the nucleus showed an obvious nucleolus (Figs. 13 \& 14). There were cells in vegetative division in which daughter cells were loosely packed (Fig. 13). After rupture of the mother cell wall, clusters of daughter cells in close contact and surrounded by a broken mother cell wall were fre-

Figs. 9-12. Perkinsus atlanticus. Transmission electron micrographs of cultured cells in JL-ODRP-2A medium. Fig. 9. Cell 2 d after subculture with a dense cytoplasm containing a prominent vacuoplast inside a vacuole and several lipid droplets and with a nucleus with a well-developed nucleolus (11800×). Fig. 10. Cell $5 \mathrm{~d}$ after subculture (6300×). Fig. 11 . Cell $5 \mathrm{~d}$ after subculture in vegetative multiplication showing cleavage furrows extending among the future daughter cells (arrows), and areas within the cell without cytoplasmic division (asterisks) (8700×). Fig. 12. Cells $5 \mathrm{~d}$ after subculture at different stages of division. Two mother cells having completed karyokinesis and cytokinesis (arrows) with daughter cells tightly packed (4500×). CM: cytoplasmic membrane. L: lipid droplet. Mt: mitochondrion. N: nucleus. No: nucleolus. V: vacuole. Vp: vacuoplast. W: wall 


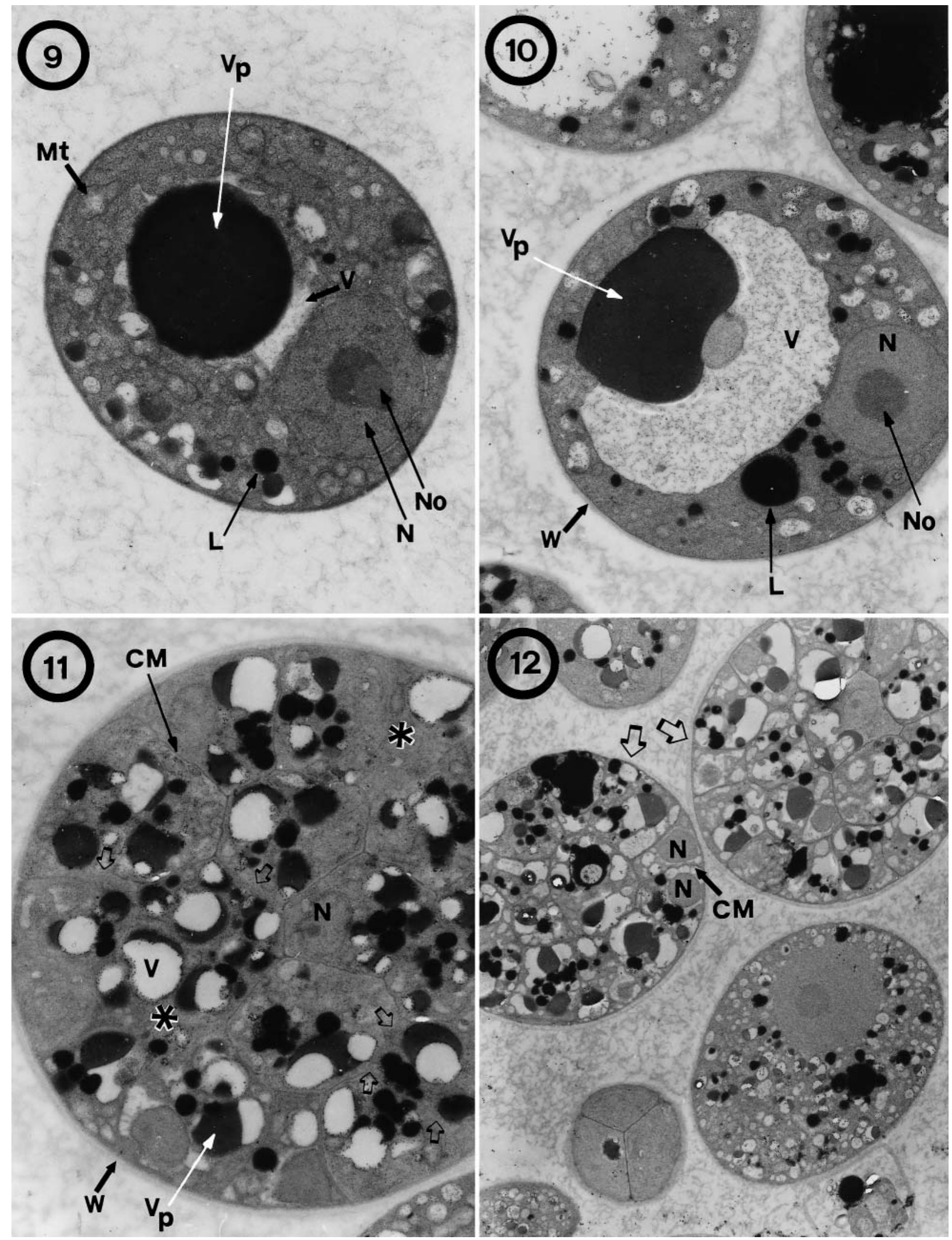




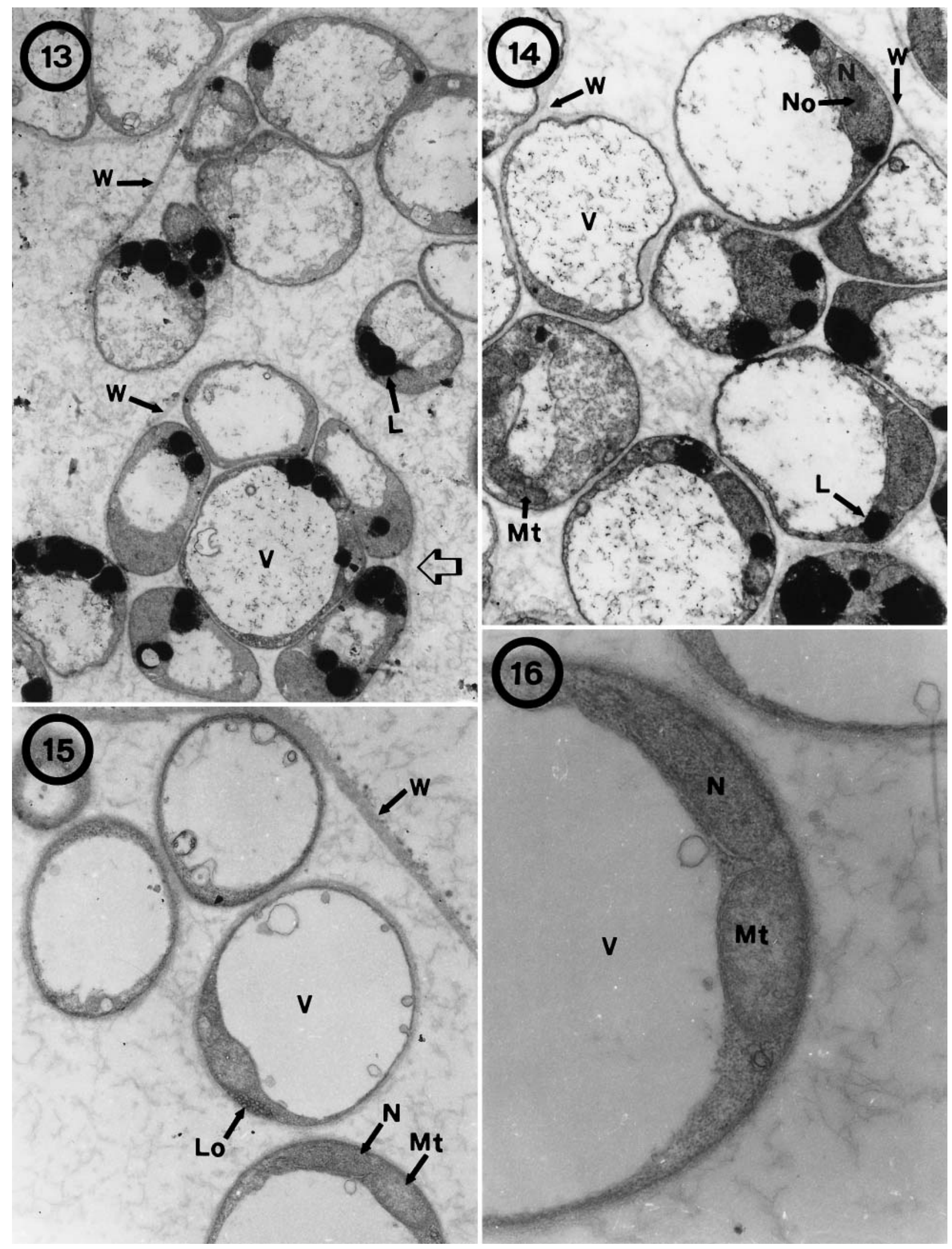


Figs. 13-16. Perkinsus atlanticus. Transmission electron micrographs of cultured cells in JL-ODRP-2A medium. Fig. 13. Cells 14 d after subculture. Mother cells in vegetative multiplication with daughter cells loosely packed (arrow), and daughter cells adhering to the ruptured cell-wall of the mother cell $(6400 \times)$. Fig. 14. Cells $14 \mathrm{~d}$ after subculture. Higher magnification of daughter cells after vegetative multiplication, still held together by the mother cell wall. Each cell had a large vacuole without vacuoplast, several droplets in their cytoplasm and a nucleus with nucleolus (9000x). Fig. 15. Cells $90 \mathrm{~d}$ after subculture with enlarged vacuole without vacuoplast $(10400 \times)$. Fig. 16. Detail of mitochondrion and nucleus of a cultured cell $90 \mathrm{~d}$ after subculture $(31900 \times)$. L: lipid droplet. Lo: lomosome. Mt: mitochondrion. N: nucleus. No: nucleolus. V: vacuole. W: wall

quently seen (Figs. 13 \& 14). Cells cultured for $90 \mathrm{~d}$ without a change of media had enlarged vacuole with no vacuoplast and flattened remaining cytoplasm and nucleus (Figs. 15 \& 16). Some vacuole protrusions and cytoplasmic vesicles were seen, whereas lipid droplets were absent (Fig. 15). Cytoplasm appeared granular with mitochondria showing tubular cristae, the nucleus was elongated and lomosomes were observed between the cell wall and plasmatic membrane (Figs. 15 \& 16).

\section{DNA sequencing}

ITS region sequences for 19 different DNA clones were obtained from 9 Perkinsus atlanticus isolate cultures. BLAST search results indicated that the closest matches of sequences from this study were to $P$. atlanticus (accession numbers PAU07697 and AF140295) and P. olseni (accession number POU07701) ITS region sequences. A consensus of optimal trees found from parsimony analysis of Perkinsus ITS region sequences is shown in Fig. 17. The numbers shown at the nodes indicate bootstrap support values. $P$. atlanticus ITS sequences from this study grouped with other $P$. atlanticus sequences and the $P$. olseni sequences with $100 \%$ bootstrap support in a clade that was sister to ITS sequences from $P$. marinus. Many of the sequences from the isolate culture DNAs were identical to Perkinsus sequences previously obtained by specific amplification of Perkinsus sequences from $P$. atlanticus-infected host tissue DNA (Casas et al. 2002).

\section{Ray test}

There was a significant $(\mathrm{p}<0.001)$ increase in the diameter of cells incubated in RFTM. The mean $( \pm \mathrm{SD}$, range) cell

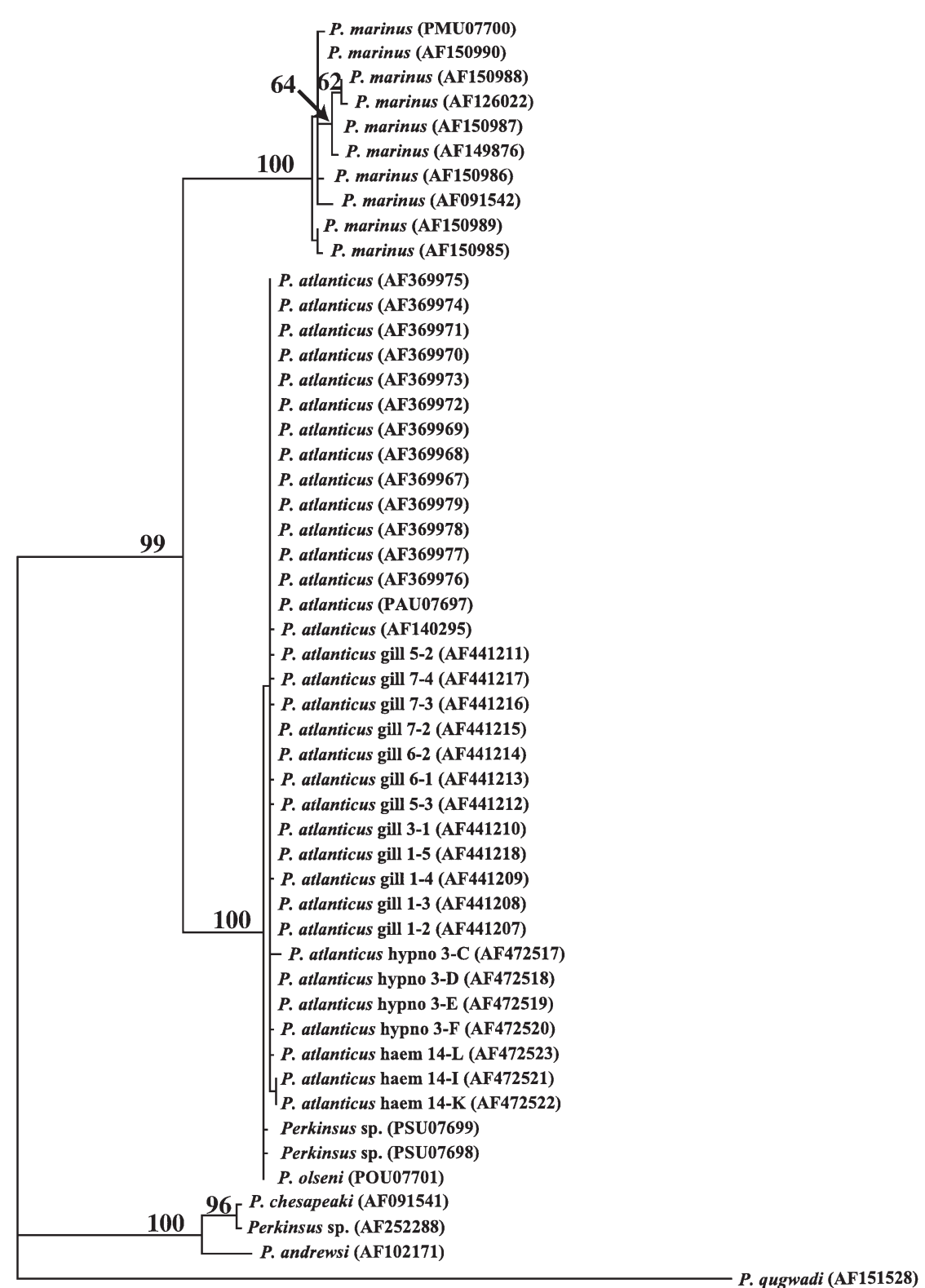

Fig. 17. Perkinsus spp. Internal transcribed spacer (ITS) region DNA sequences. Consensus of optimal trees found by parsimony analysis of the sequences for the ITS region of the ribosomal RNA complex of Perkinsus species. Numbers at nodes indicate bootstrap support values for the groups where the value was above 60. P. atlanticus sequences determined for this study are designated as 'gill' for sequences obtained from cultures initiated from gill fragments, 'hypno' for sequences obtained from cultures initiated from hypnospores and 'haem' for sequences obtained from cultures initiated from haemolymph 
diameter of cultures established from gill fragments was $8.8 \pm 2.93 \mu \mathrm{m}$ (5 to $20 \mu \mathrm{m}$ ) before incubation in RFTM and $25.3 \pm 8.08 \mu \mathrm{m}(10$ to $60 \mu \mathrm{m})$ after incubation in RFTM. The mean cell diameter of cultures established from haemolymph was $10.0 \pm 5.02 \mu \mathrm{m}$ (5 to $22.5 \mu \mathrm{m})$ before incubation in RFTM and $26.0 \pm$ $9.06 \mu \mathrm{m}(10$ to $60 \mu \mathrm{m})$ after incubation in RFTM. The mean cell diameter of cultures established from hynospores was $7.3 \pm 4.41 \mu \mathrm{m}(2.5$ to $27.5 \mu \mathrm{m})$ before incubation in RFTM and $15.4 \pm 4.29 \mu \mathrm{m}$ ( 7.5 to $32.5 \mu \mathrm{m}$ ) after incubation in RFTM. The percent viability of cells, after incubation in RFTM, from cultures established from gill fragments was $34.2 \%$, from haemolymph $28.3 \%$, and from hypnospores $47.1 \%$. All enlarged cells stained blue-black with Lugol's solution.

\section{Quantitation of growth}

A typical growth curve for cultured cells is shown in Fig. 18. During the first couple of days after seeding the flasks, cells enlarged and accumulated lipid droplets in the cytoplasm. On Day 2, there were significant differences $(p<0.0001)$ in mean cell diameter

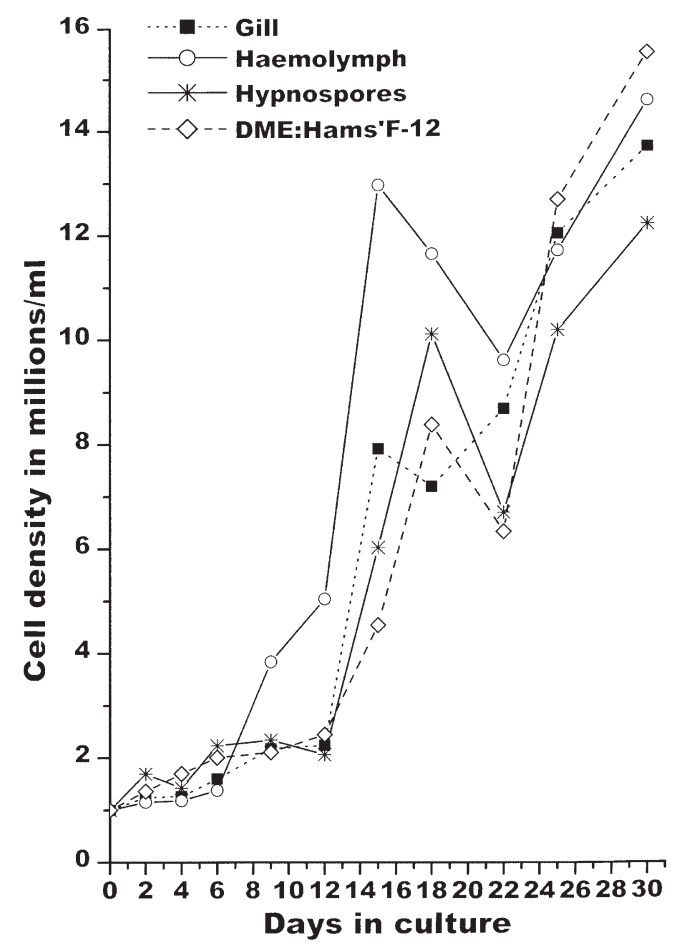

Fig. 18. Perkinsus atlanticus. Propagation of cells in JLODRP-2A medium of cultures established from gills, haemolymph and hypnospores, and propagation in vitro of $P$. atlanticus cells in DME:Ham's F-12 medium of cultures established from gills. Triplicate flasks were seeded with $10^{6}$ cells ml-1 from each source and flasks were incubated at $26^{\circ} \mathrm{C}$ between cultures established from gill fragments, haemolymph and hypnospores. Mean $( \pm \mathrm{SD})$ cell diameter for cultures established from gill fragments was $8.7 \pm 3.54 \mu \mathrm{m}(\mathrm{N}=201$, range: 4.9 to $31.8 \mu \mathrm{m})$, from haemolymph $10.0 \pm 4.56 \mu \mathrm{m}(\mathrm{N}=216,4.9$ to $36.7 \mu \mathrm{m})$, and from hypnospores $7.3 \pm 3.22 \mu \mathrm{m}(\mathrm{N}=$ $214,2.4$ to $29.4 \mu \mathrm{m})$. On Day 4, the mean diameters of cells from cultures established from gill fragments $(10.1 \pm 2.48 \mu \mathrm{m} ; \mathrm{N}=163,5$ to $15 \mu \mathrm{m})$ and haemolymph $(10.4 \pm 2.61 \mu \mathrm{m} ; \mathrm{N}=252,5$ to $20 \mu \mathrm{m})$ were significantly higher than the mean diameter of cells from cultures established from hypnospores (9.0 $\pm 2.62 \mu \mathrm{m}_{i} \mathrm{~N}=297,5$ to $\left.32.5 \mu \mathrm{m}\right)$. Cell division usually started on Day 4. On Day 6 more than $50 \%$ of cells were dividing by vegetative multiplication. A few zoosporulating cells (less than $1 \%$ of dividing cells) were observed in every culture flask. The mean $( \pm \mathrm{SD})$ diameter of cells involved in vegetative multiplication was $16.0 \pm 3.55 \mu \mathrm{m}(\mathrm{N}=83,7.4$ to $27.0 \mu \mathrm{m})$ for cultures established from gill fragments, $19.7 \pm$ $6.04 \mu \mathrm{m}(\mathrm{N}=44,9.8$ to $44.1 \mu \mathrm{m})$ for cultures established from haemolymph, and $13.0 \pm 3.62 \mu \mathrm{m}(\mathrm{N}=78$, 7.3 to $31.8 \mu \mathrm{m}$ ) for cultures established from hypnospores. The mean number of daughter cells per mother cell $( \pm \mathrm{SD})$ was $12.5 \pm 5.74(\mathrm{~N}=78,4$ to 32 cells) for cultures established from gill fragments, $20.4 \pm 14.10(\mathrm{~N}=36,6$ to 60 cells $)$ for cultures established from haemolymph, and $8.7 \pm 7.41(\mathrm{~N}=$ 71,2 to 60 cells) for cultures established from hypnospores. There were significant differences in mean diameter of cells in vegetative multiplication ( $p<$ 0.0001 ) and in the number of daughter cells per mother cell $(p>0.0001)$ between cultures established from different sources.

In JL-ODRP-2A, cultures established from haemolymph, gill fragments and hypnospores differed in their period of highest increase in cell number (i.e. log phase of growth). Log growth phase for cultures established from haemolymph occurred between Days 6 and 15; from gill fragments between Days 12 and 15; and from hypnospores between Days 12 and 18. Log growth phase for cultures in the commercial medium DME:Ham's F-12 supplemented with fetuin occurred between Days 12 and 18. Mean doubling times $( \pm \mathrm{SD})$ for cultures established from haemolymph was $26.2 \pm$ $6.89 \mathrm{~h}$; from gill fragments $29.6 \pm 8.61 \mathrm{~h}$; and from hypnospores $42.3 \pm 29.84 \mathrm{~h}$. No significant difference in doubling times between cultures established from haemolymph, gill fragments and hypnospores was found $(p=0.55)$. Mean doubling times $( \pm S D)$ for cultures established from gill fragments incubated in DME:Ham's F-12 was $84.5 \pm 84.46$ h. No difference in doubling times was observed between cultures established from gills in medium JL-ODRP-2A and those DME:Ham's F-12 ( $p=0.32)$. 


\section{DISCUSSION}

Continuous cultures of Perkinsus atlanticus were established for the first time. The morphology of cells in cultures, at the light and electron microscopy levels, were typical of $P$. atlanticus and other Perkinsus spp. Cultured cells incubated in RFTM produced enlarged cells (hypnospores) that stained blue-black in Lugol's solution, a response characteristic of Perkinsus spp. and used in routine diagnosis. Species identification of the cultured cells was accomplished through analysis of nucleotide sequences of the ITS region of the rRNA gene complex, which matched that of $P$. atlanticus.

Cultures were successfully established from 3 sources of parasites, the gills and haemolymph of infected carpet shell clams and from hypnospores isolated from infected gill fragments after incubation in RFTM. However, no culture could be established with isolated zoospores. Cultures initiated from gill fragments and hypnospores yielded the highest percentage of continuous cultures, 93 and $100 \%$ respectively. The majority of cultures initiated from haemolymph became contaminated with bacteria or protozoa, and only $30 \%$ yielded continuous cultures. All contaminated cultures were discarded because past attempts to eliminate microbial contaminants generally have been unsuccessful and a drain on resources (J. F. La Peyre pers. obs.).

Perkinsus spp. cultures have been established from a variety of tissues including hearts, visceral ganglia and gills (Kleinschuster \& Swink 1993, La Peyre et al. 1993, McLaughlin \& Faisal 1998, Coss et al. 2001a) but there is little information on the optimal source of parasites to use. The success rate in establishing continuous cultures can be used as a criterion for selecting a tissue as a source of parasites. In this study, the success rate of establishing continuous cultures of $P$. atlanticus depended primarily on the absence of microbial contamination because all cultures were initiated from infected clams. Oyster hearts were used for the first time to establish $P$. marinus cultures because this organ is relatively free of microbial contaminants compared to other oyster tissues (La Peyre et al. 1993). In the current study, gills of carpet shell clams were used instead of hearts to establish $P$. atlanticus cultures because the clam heart is traversed by the intestine, thus increasing the chance of microbial contamination. Gills of $T$. decussatus are also one of the clams' organs most infected with P. atlanticus (Azevedo 1989, Rodríguez \& Navas 1995). Using gill tissues has the advantage that sites of infections can be easily located by looking for abscesses and hence tissues with a high parasite load can be selected to initiate cultures. Depuration of the clams, thorough rinsing of gill tissues in saline (i.e. 20 times) and decontamination of the gill tissues in antibiotic solutions were essential steps in reducing microbial contamination to establish continuous cultures of $P$. atlanticus from carpet shell clam gills. The $93 \%$ success rate in establishing $P$. atlanticus continuous cultures from gills of infected clams indicates the gill tissue is a good choice as a source of parasites.

Haemolymph also has been used to establish Perkinsus spp. cultures (Gauthier \& Vasta 1993, Kleinschuster et al. 1994, Dungan \& Hamilton 1995, McLaughlin \& Faisal 1998). In the current study, microbial contamination of cultures initiated from clam haemolymph was more frequent than in cultures initiated from gills or hypnospores. This is not unexpected since bivalve haemolymph is seldom sterile and microorganisms such as algae and bacteria are often found in haemocytes following feeding. Establishing continuous cultures of Perkinsus spp. from haemolymph is therefore more difficult than from other tissues. Perhaps the decontamination procedure before seeding should be improved, although within haemocytes microorganisms cannot be rinsed off and the efficacy of antibiotic decontamination solutions is greatly reduced. One advantage of using haemolymph is that the mollusc does not have to be sacrificed, possibly enabling mollusc investigations on the contribution of different parasite strains during the progression of Perkinsus infection.

Another criterion for selecting a tissue as a source of parasites could be the time taken to establish continuous cultures. Perkinsus marinus cultures, for example, were established more rapidly from hypnospores than from hearts of eastern oysters (La Peyre \& Faisal 1995). Culture flasks $\left(25 \mathrm{~cm}^{2}\right)$ seeded with $10^{5} \mathrm{P}$. marinus hypnospores contained up to $10^{7}$ cells per flask after $2 \mathrm{wk}$ in cultures while 4 to $8 \mathrm{wk}$ were generally needed to obtain similar numbers of $P$. marinus cells in cultures initiated from hearts of infected eastern oysters. In $P$. atlanticus cultures initiated with hypnospores, the parasite cells began to divide and produce new cells earlier than in cultures established from clam gills or haemolymph. The number of cultures that can be produced from the hypnospores isolated from a single clam can also be high because millions of hypnospores can be isolated from a heavily infected clam. Hypnospores have been used to establish a number of Perkinsus spp. cultures (La Peyre \& Faisal 1995, Bushek \& Allen 1996b, McLaughlin \& Faisal 1998). However, the success rate in establishing cultures from hypnospores is generally much lower than the success rate in establishing cultures from oyster hearts because of microbial contamination. About $90 \%$ of cultures initiated from oyster heart tissues yield continuous cultures of $P$. marinus compared to about a 20 to $30 \%$ success rate for cultures initiated from P. marinus hypnospores (J. F. La Peyre pers. obs., D. Bushek pers. comm.). The much 
higher success rate $(100 \%)$ in establishing $P$. atlanticus cultures from hypnospores is probably due to the thorough decontamination procedure used in the current study. Gill fragments were decontaminated before incubation in RFTM and again after 1 wk incubation in RFTM before inoculation of the culture flasks. Isolated hypnospores are therefore another good source of parasites to establish continuous cultures of $P$. atlanticus.

No culture could be established when Perkinsus atlanticus zoospores were added to culture medium. It is not known whether the failure of zoospores to yield continuous cultures was related to the isolation method (centrifugation at high speed, $3000 \times g$ ) or just to the nature of zoospores. Results from this study contrast with reports of the transformation of zoospores into trophozoites and the subsequent growth in other Perkinsus spp. (Kleinschuster et al. 1994, La Peyre \& Faisal 1995, Coss et al. 2001a). The role of zoospores in the life cycle of Perkinsus spp. is still unclear and further studies on the fate of zoospores are needed.

Continuous cultures of Perkinsus atlanticus can be established from a variety of parasite sources with varying levels of success. Success rates of establishing cultures were provided for the first time and will be useful to other researchers in selecting a source of parasites to culture additional isolates of $P$. atlanticus and other Perkinsus spp. However, some caution must be exercised when choosing a source of parasites because preliminary results indicate that certain characteristics of Perkinsus cells in culture, such as size, growth rate and protein secretion, can vary depending on the source of parasites used to initiate the cultures. In the current study, the source of parasites influenced the size of $P$. atlanticus cells. Cells from cultures initiated with hypnospores were significantly smaller than cells from cultures initiated from gills or haemolymph. Furthermore, the size of cells in vegetative division and the number of daughter cells per mother cell was significantly different depending on source of $P$. atlanticus cultured cells. The source of parasite cells also can influence the production of extracellular proteins by cultured cells. Differences in production of extracellular proteins between $P$. marinus cultures established from hypnospores and oyster hearts have been noted by La Peyre \& Cooper (1997). In P. atlanticus differences in production of extracellular proteins in cultures from different sources of parasite cells have also been observed (S. M. Casas unpubl. results). Therefore, it is critical that the sources of parasites used to establish cultures are reported in any studies involving cultured Perkinsus spp. until more is known about the reasons for these differences.

The cultured Perkinsus atlanticus cells had all morphological characteristics of Perkinsus spp. parasites at the light and electron microscopic levels (La Peyre et al.
1993, Perkins 1996, Coss et al. 2001a, Sunila et al. 2001). The sizes of the cultured mature trophozoites of $P$. atlanticus established from various sources were larger than the size of mature trophozoites from clam tissues, which generally did not exceed $15 \mu \mathrm{m}$ (S. M. Casas pers. obs.). Similarly, multinucleated cells in the vegetative division process were larger in culture than in clam tissues (range 7 to $15 \mu \mathrm{m}$; S. M. Casas pers. obs.) and the number of daughter cells produced by mother cells was also higher in culture. Cell sizes have been shown to vary substantially depending on the host (Goggin \& Lester 1995) and the time of year (Ray \& Chandler 1955, Bushek et al. 1994), and can be influenced by nutrient availability, which may explain the differences between cultured cells and cells in histological sections (La Peyre et al. 1993, La Peyre \& Faisal 1996).

Vegetative multiplication of Perkinsus marinus in its host occurs by successive bipartition in which karyokinesis is followed by cytokinesis (binary fission) (Perkins 1996). Light microscopy and TEM observation of in vitro $P$. atlanticus cultures suggested that vegetative multiplication occurs mostly by multiple fission; that is to say, multiple karyokinesis occurred before cytokinesis took place. Sunila et al. (2001) observed with TEM that schizogony was the most common mode of cell division of cultured $P$. marinus cells and that binary fission occurred rarely.

Zoosporulation yielding motile zoospores was observed at a low ( $<1 \%$ of dividing cells) frequency in every Perkinsus atlanticus culture established from gills, haemolymph and hypnospores in the culture medium JL-ODRP-2A. Zoosporulation of cultured vegetative cells of Perkinsus spp. established from several clam species has also been reported in culture media (Kleinschuster et al. 1994, McLaughlin \& Faisal 1998, Coss et al. 2001a). In contrast, zoosporulation of vegetative cells from established cultures of $P$. marinus has not been reported. The significance of these observations to species identity and host specificity is not yet known.

A characteristic of protozoa in the genus Perkinsus is their ability to enlarge in RFTM and stain blue-black with Lugol's solution. This characteristic discovered by Ray (1952) is the basis of a common diagnostic test for infection (Ray 1952, 1966, reviewed by Bushek et al. 1994). Only 1 Perkinsus species, P. qugwadi in bay scallops, does not enlarge in RFTM but there is doubt that this parasite belongs in the genus Perkinsus. In addition to the inability of $P$. qugwadi to enlarge in RFTM and to stain blue black with Lugol's solution, differences in morphology and considerable differences in DNA sequences of the ITS region of the ribosomal RNA gene complex between $P$. qugwadi and other Perkinsus spp. have been found (Coss et al. 2001b, Casas et al. 2002). In this study, the size of 
cultured cells incubated in RFTM increased significantly and the enlarged cells stained with Lugol's solution. However, cultured cells incubated in RFTM were generally smaller than hypnospores isolated from infected gills (38.9 $\pm 10.4 \mu \mathrm{m}$, range 19.7 to $64.1 \mu \mathrm{m} ; \mathrm{S}$. M. Casas pers. obs.). Reduced enlargement of cultured cells compared to hypnospores in RFTM also has been observed in previous studies (Gauthier \& Vasta 1993, Kleinschuster \& Swink 1993, La Peyre et al. 1993). In vitro studies with cultured cells indicate that enlargement can be greatly increased by the addition of lipid and other nutrients to RFTM (La Peyre 1996, Wagner et al. 2001). The larger size of $P$. atlanticus in gill tissues incubated in RFTM could reflect additional nutrients available from the carpet shell clam tissue.

Agreement in morphology between cultured cells and Perkinsus cells from host tissues is essential for genus identification but not sufficient for species identification. In some cases, protozoans that were initially described as Perkinsus spp. based partly on their morphologies were later found not to belong in the genus Perkinsus (McGladdery et al. 1991, Goggin et al. 1996, Ordás \& Figueras 1998, Figueras et al. 2000). Currently, as mentioned above, classification of $P$. qugwadi, is questionable because of noted differences in morphology from that which is the typical morphology of Perkinsus spp. (Blackbourn et al. 1998). Therefore, the morphology of putative Perkinsus spp. must be examined with extreme care at both the light and electron microscopic levels before they are included in this genus.

Other characteristics and data such as DNA sequences can be used in combination with cell morphology to identify protozoan parasites as Perkinsus spp. at the genus level and are required for accurate species identification within this genus. In this study DNA sequences of the ITS region helped to confirm the identification of cultures as $P$. atlanticus. The ITS region sequences from cultures established from gills and haemolymph of infected clams, as well as those from isolated hypnospore cultures grouped in phylogenetic analyses with previously published $P$. atlanticus and $P$. olseni sequences. Many sequences were identical to those obtained from parasite infected $T$. decussatus tissues (Goggin 1994, Robledo et al. 2000, Casas et al. 2002). The ITS region sequences can be used to distinguish many Perkinsus species, although neither $P$. olseni and $P$. atlanticus nor $P$. chesapeaki and $P$. andrewsi can be resolved using ITS sequences (see Fig. 17). A recent study, however, has reported that ITS sequences previously thought to distinguish $P$. chesapeaki and $P$. andrewsi are really ITS variants that can both be found in a single clonal isolate culture (Dungan et al. 2002). This result suggests that $P$. chesapeaki and P. andrewsi are the same species of Perkin- sus. In addition, based on the sequence analyses to date, it is likely that $P$. atlanticus and $P$. olseni are the same Perkinsus species; clonal cultures of each will be required to accurately address this question.

The culture medium JL-ODRP-2A, used to culture Perkinsus marinus, supported the proliferation of $P$. atlanticus. P. atlanticus could also be grown in the commercial medium 1:2 DME:Ham's F-12 supplemented with fetuin as prepared by Gauthier et al. (1995). No difference in P. atlanticus growth rate was found between these 2 media. An advantage of using the medium JL-ODRP-2A is that its nutrient composition can be easily adjusted to optimise $P$. atlanticus growth in vitro. Moreover, JL-ODRP-2A does not contain proteins so that studies on the production of extracellular proteins by cultured $P$. atlanticus are facilitated (La Peyre et al. 1995, La Peyre \& Faisal 1996). There were some differences in proliferation patterns and cell sizes of cultures established from gills, haemolymph and hypnospores but their DTs were not significantly different. The DTs of the 9 isolates were variable but comparable to the DTs reported for other Perkinsus spp. (Kleinshuster et al. 1994, Dungan \& Hamilton 1995, Gauthier \& Vasta 1995, La Peyre \& Faisal 1996). However, strict comparison of Perkinsus spp. growth rates is not possible because of many differences between studies, such as in media, isolates, seeding densities, proliferation assays and the period of cell proliferation selected to calculate DT (La Peyre 1996).

The experience acquired with culturing Perkinsus marinus facilitated the in vitro culture of $P$. atlanticus and other Perkinsus spp. The optimal culture conditions for $P$. atlanticus will need to be determined by measuring the effects of various physical and chemical parameters such as temperature, salinity, $\mathrm{pH}$, inoculum density and nutrient concentrations on the parasite growth. As with $P$. marinus, $P$. atlanticus cultures can be used in a wide range of studies to address important questions such as about the parasite's environmental tolerance, virulence, genetic make up, metabolism and drug sensitivity. The development of continuous cultures of $P$. atlanticus will lead to better understanding of this important parasite of carpet shell clams.

Acknowledgements. María Jesús Llevot, Kathleen Apakupakul, and Laura Corral provided technical assistance. José Ignacio Navas (CICEM 'Agua del Pino', Junta de Andalucía) provided the protocol to isolate hypnospores. This work was partially supported by funds of the Secretaría Xeral de Investigación e Desenvolvemento Tecnolóxico da Xunta de Galicia, through the project PGIDT-CIMA 99/10 and by funds from the Louisiana Sea Grant College Program. S.M.C. was supported by a scholarship from the Consellería de Pesca, Marisqueo e Acuicultura, Xunta de Galicia. Financial support 
included funding for her stay at the J.F.L.P. laboratory, Louisiana State University. This is contribution no. 2471 of the Virginia Institute of Marine Science, College of William and Mary.

\section{LITERATURE CITED}

Altschul SF, Gish W, Miller W, Myers EW, Lipman DJ (1990) Basic local alignment search tool. Mol Biol 215:403-410

Azevedo C (1989) Fine structure of Perkinsus atlanticus n. sp. (Apicomplexa, Perkinsea) parasite of the clam Ruditapes decussatus from Portugal. J Parasitol 75:627-635

Blackbourn J, Bower SM, Meyer GR (1998) Perkinsus qugwadi sp. nov. (incertae sedis), a pathogenic protozoan parasite of Japanese scallops, Patinopecten yessoensis, cultured in British Columbia, Canada. Can J Zool 76:942-953

Burreson EM, Ragone Calvo LM, La Peyre JF, Counts F, Paynter KT (1994) Acute osmotic tolerance of cultured cells of the oyster pathogen Perkinsus marinus (Apicomplexa: Perkinsida). Comp Biochem Physiol 109A:575-582

Bushek D, Allen SK (1996a) Races of Perkinsus marinus. J Shellfish Res 15:103-107

Bushek D, Allen SK (1996b) Host-parasite interactions among broadly distributed populations of the eastern oyster Crassostrea virginica and the protozoan Perkinsus marinus. Mar Ecol Prog Ser 139:127-141

Bushek D, Ford SE, Allen SK (1994) Evaluation of methods using Ray's fluid thioglycollate medium for diagnosis of Perkinsus marinus infection in the eastern oyster, Crassostrea virginica. Annu Rev Fish Dis 4:201-217

Casas SM, Villalba A, Reece KS (2002) Study of perkinsosis in the carpet shell clam Tapes decussatus in Galicia (NW Spain). I. Identification of the aetiological agent and in vitro modulation of zoosporulation by temperature and salinity. Dis Aquat Org 50(1):51-65

Chu FLE, Greene KH (1989) Effect of temperature and salinity on in vitro culture of the oyster pathogen, Perkinsus marinus (Apicomplexa: Perkinsea ). J Invertebr Pathol 53: 260-268

Coss CA, Robledo JAF, Vasta GR (2001a) Fine structure of clonally propagated in vitro life stages of a Perkinsus sp. isolated from the Baltic clam Macoma balthica. J Eukaryot Microbiol 48:38-51

Coss CA, Robledo JAF, Ruiz GM, Vasta GR (2001b) Description of Perkinsus andrewsi n. sp. isolated from the Baltic clam (Macoma balthica) by characterization of the ribosomal RNA locus, and development of a species-specific PCR-based diagnostic assay. J Eukaryot Microbiol 48: $52-61$

de la Herrán R, Garrido-Ramos MA, Navas JI, Ruiz-Rejón C, Ruiz-Rejón M (2000) Molecular characterization of the ribosomal RNA gene region of Perkinsus atlanticus: its use in phylogenetic analysis and as a target for a molecular diagnosis. Parasitology 120:345-353

Dungan CF, Hamilton RM (1995) Use of the tetrazoliumbased cell proliferation assay to measure effects of in vitro conditions on Perkinsus marinus (Apicomplexan) proliferation. J Eukaryot Microbiol 42:379-388

Dungan CF, Hamilton RM, Hudson KL, McCollough CB, Reece KS (2002) Two epizootic infectious diseases in Chesapeake Bay commercial clams, Mya arenaria and Tagelus plebius. Dis Aquat Org 50(1):67-78

Faisal M, La Peyre JF, Elsayed E, Wright DC (1999) Bacitracin inhibits the oyster pathogen Perkinsus marinus in vitro and in vivo. J Aquat Anim Health 11:130-138

Figueras A, Lorenzo G, Ordás MC, Gouy M, Novoa B (2000)
Sequence of the small subunit ribosomal RNA gene of Perkinsus atlanticus-like isolated from carpet shell clam in Galicia, Spain. Mar Biotechnol 2:419-428

Gauthier J, Vasta G (1993) Continuous in vitro culture of the eastern oyster parasite Perkinsus marinus. J Invertebr Pathol 62:321-323

Gauthier J, Vasta G (1995) In vitro culture of the eastern oyster parasite Perkinsus marinus: optimization of the methodology. J Invertebr Pathol 66:156-168

Gauthier JD, Feig B, Vasta GR (1995) Effect of fetal bovine serum glycoproteins on the in vitro proliferation of the oyster parasite Perkinsus marinus: development of a fully defined medium. J Eukaryot Microbiol 42:307-313

Goggin CL (1994) Variation in the two internal transcribed spacers and 5.8S ribosomal RNA from five isolates of the marine parasite Perkinsus (Protista, Apicomplexa). Mol Biochem Parasitol 65:179-182

Goggin CL, Lester RJG (1995) Perkinsus, a protistan parasite of abalone in Australia: a review. Mar Freshw Res 46: 639-646

Goggin CL, McGladdery SE, Whyte SK, Cawthorn RJ (1996) An assessment of lesions in bay scallops Argopecten irradians attributed to Perkinsus karlssoni (Protozoa, Apicomplexa). Dis Aquat Org 24:77-80

Kleinschuster SJ, Swink SL (1993) A simple method for the in vitro culture of Perkinsus marinus. Nautilus 107:76-78

Kleinschuster SJ, Perkins FO, Dykstra MJ, Swink SL (1994) The in vitro life cycle of a Perkinsus species (Apicomplexa, Perkinsidae) isolated from Macoma balthica (Linnaeus, 1758). J Shellfish Res 13:461-465

Kotob SI, McLaughlin SM, Van Berkum P, Faisal M (1999) Characterization of two Perkinsus spp. from the softshell clam, Mya arenaria using the small subunit ribosomal RNA gene. J Eukaryot Microbiol 46:439-444

Krantz GE (1994) Chemical inhibition of Perkinsus marinus in two in vitro culture systems. J Shellfish Res 13:131-136

La Peyre JF (1996) Propagation and in vitro studies of Perkinsus marinus. J Shellfish Res 15:89-101

La Peyre JF, Cooper RK (1997) Changes in protease expression by Perkinsus marinus cultures following incubation in Ray's fluid thioglycollate medium. J Shellfish Res 16:331

La Peyre JF, Faisal M (1995) Improved method for the initiation of continuous cultures of the oyster pathogen Perkinsus marinus (Apicomplexa). Trans Am Fish Soc 124: 144-146

La Peyre JF, Faisal M (1996) Optimal culture conditions for the propagation of the oyster pathogen Perkinsus marinus (Apicomplexa) in protein deficient medium. Parasite 3: $147-153$

La Peyre JF, Faisal M, Burreson EM (1993) In vitro propagation of the protozoan Perkinsus marinus, a pathogen of the eastern oyster, Crassostrea virginica. J Eukaryot Microbiol 40:304-310

La Peyre JF, Schafhauser DY, Rizkalla EH, Faisal M (1995) Production of serine proteases by the oyster pathogen Perkinsus marinus (Apicomplexa) in vitro. J Eukaryot Microbiol 42:544-551

McGladdery SE, Cawthorn RJ, Bradford BC (1991) Perkinsus karlssoni n. sp. (Apicomplexa) in bay scallops Argopecten irradians. Dis Aquat Org 10:127-137

McLaughlin SM, Faisal M (1998) In vitro propagation of two Perkinsus species from the softshell clam Mya arenaria. Parasite 5:341-348

McLaughlin SM, Tall BD, Shaheen A, Elsayed EE, Faisal M (2000) Zoosporulation of a new Perkinsus species isolated from the gills of the softshell clam Mya arenaria. Parasite $7: 115-122$ 
Nickens AD, Wagner E, La Peyre JF (2000) Improved procedure to count Perkinsus marinus in eastern oyster hemolymph. J Shellfish Res. 19:665

Ordás MC, Figueras A (1998) In vitro culture of Perkinsus atlanticus, a parasite of the carpet shell clam Ruditapes decussatus. Dis Aquat Org 33:129-136

Perkins FO (1996) The structure of Perkinsus marinus (Mackin, Owen \& Collier, 1950) Levine, 1978 with comments on taxonomy and phylogeny of Perkinsus spp. J Shellfish Res 15:67-88

Perkins FO, Menzel RW (1966) Morphological and cultural studies of a motile stage in the life cycle of Dermocystidium marinum. Proc Natl Shellfish Assoc 56:23-30

Ray SM (1952) A culture technique for the diagnosis of infections with Dermocystidium marinum Mackin, Owen, and Collier in oysters. Science 116:360-361

Ray SM (1966) A review of the culture method for detecting Dermocystidium marinum, with suggested modifications and precautions. Proc Natl Shellfish Assoc 54:55-69

Ray SM, Chandler AC (1955) Dermocystidium marinum, a parasite of oysters. Exp Parasitol 4:172-200

Reece KS, Bushek D, Graves JE (1997) Molecular markers for population genetic analysis of Perkinsus marinus. Mol Mar Biol Biotech 6:197-206

Reece KS, Bushek D, Hudson KL, Graves JE (2001) Geographic distribution of Perkinsus marinus genetic strains along the Atlantic and Gulf coasts of the USA. Mar Biol 139:1047-1055

Robledo JAF, Coss CA, Vasta GR (2000) Characterisation of the ribosomal RNA locus of Perkinsus atlanticus and development of a polymerase chain reaction-based diagnostic assay. J Parasitol 86:972-978

Rodríguez F, Navas JI (1995) A comparison of gill and hemolymph assays for the thioglycollate diagnosis of Perkinsus atlanticus (Apicomplexa, Perkinsea) in clams, Ruditapes decussatus (L.) and Ruditapes philippinarum (Adams et Reeve). Aquaculture 132:145-152

Ruano F, Cachola R (1986) Outbreak of a severe epizootic of

Editorial responsibility: Albert Sparks,

Seattle, Washington, USA
Perkinsus marinus (Levin - 78) at Ria de Faro clam's culture beds. In: Abstracts 2nd Int Colloq Pathol Mar Aquac (PAMAQ II). University of Oporto, Porto, Portugal, p 41-42

Santmartí, MM, García Valero J, Montes J, Pech A, Durfort M (1995) Seguimiento del protozoo Perkinsus sp. en las poblaciones de Tapes decussatus y Tapes semidecussatus del delta del Ebro. In: Castelló F, Calderer A (eds) Actas del V Congreso Nacional de Acuicultura, May 10-13, 1995, S. Carlos de la Rápita, Spain. Universidad de Barcelona, p 260-265

Soudant P, Chu FLE (2001) Lipid class and fatty acid composition of the protozoan parasite of oysters, Perkinsus marinus cultivated in two different media. J Eukaryot Microbiol 48:309-319

Soudant, P, Chu FLE, Manty Y (2000) Lipid class composition of the protozoan Perkinsus marinus an oyster parasite, and its metabolism of a fluorescent phosphatidycholine analog. Lipids 35:1387-1395

Sunila I, Hamilton RM, Dungan CF (2001). Ultrastructural characteristics of the in vitro cell cycle of the protozoan pathogen of oysters, Perkinsus marinus. J Eukaryot Microbiol 48:348-361

Swofford DL (2001) PAUP*. Phylogenetic analysis using parsimony (*and other methods), Version 4. Sinauer Associates, Sunderland, MA

Thompson JD, Higgins DG, Gibson TJ (1994) Improving the sensitivity of progressive multiple sequence alignment through sequence weighting, positions-specific gap penalties and weight matrix choice. Nucleic Acids Research 22:4673-4680

Volety AK, Chu FLE (1997) Acid phosphatase activity in Perkinsus marinus, the protistan parasite of the American oyster, Crassostrea virginica. J Parasitol 83:1093-1098

Wagner E, Casas SM, La Peyre JF (2001) Induction of hypnospore formation and zoosporulation of Perkinsus marinus cells from long term cultures. In: Devoe R (ed) Abstracts from Aquaculture 2001. World Aquaculture Society, Lake Buena Vista, FL, p 670

Submitted: February 1, 2002; Accepted: May 8, 2002 Proofs received from author(s): December 2, 2002 